\title{
Armahdus länsimaiselle suorittajalle
}

Timo Klemola (2013): Mindfulness - Tietoisuuden harjoittamisen taito.

Docendo: Jyväskylä. $221 \mathrm{~s}$.

ISBN 978-952-5912-74-6.

Mietiskely, meditaatio - tietoisuuden harjoittaminen mielen ja kehon harjoituksessa - on ikivanha osa idän uskontoja ja itsekasvatusperinteitä. Vaikka mietiskelyä on harjoitettu myös kristillisessä perinteessä, länsimaissa oppia on haettu aina idän kulttuureilta. Viimeisin mielenkiinnon aalto lienee viime vuosikymmeninä levinnyt kiinnostus buddhalaiseen tietoisuuden harjoittamisen perinteeseen, niin kutsuttuun mindfulnessiin. Sen sovellukset ovat laajat ja niitä on tutkittu paljon etenkin käyttäytymisterapiassa. Mindfulness valtaa vauhdilla alaa myös itsenkehittämismarkkinoilla ja työelämässä.

Mindfulness - Tietoisuuden harjoittamisen taito -teoksen kirjoittaja Timo Klemola on filosofi, rinzai-zenin aktiiviharjoittaja ja kokenut mindfulness-kouluttaja. Hän on myös harrastanut budolajeja ja kehittänyt työtovereineen asahi-nimisen terveysliikunnan. Klemola sijoittaa mindfulnessin sen buddhalaisiin juuriin. Hän esittelee buddhalaisuutta tieteenä, torjuen uskonnolliset tai new age -konnotaatiot. Koska peilauspintana on fenomenologinen filosofia, kirja puhuttelee akateemista lukijaa ja auttaa hahmottamaan buddhalaisen perinteen perusoletuksia ihmismielestä. Klemola kuvaa mindfulnessin, ei kognitiivisena tekniikkana, vaan buddhalaisen perinteen kontekstissa osana kokonaista elämänmuotoa, filosofiaa ja etiikkaa. Tarkkaavaisuuden harjoittaminen onkin itse asiassa osa laajempaa buddhalaista perinnettä, niin sanotun kahdeksanosaisen polun seitsemäs osa.
Kirja hyödyntää kysymys-vastaus-rakennetta oppilaan kysymyksinä opettajalle. Tekstiin on näin saatu dialoginen rakenne ja samalla kiitettävän analyyttinen ote. Rakenne lienee seurausta siitä, että kirja on syntynyt koulutusmateriaalien pohjalta. Lisäksi se kaiuttaa buddhalaisen perinteen mukaista tapaa oppia suorasta dialogista mestarin kanssa. Käsitteelliseen pohdintaan liittyy runsaasti harjoituksia, joita lukija kutsutaan tekemään lukemisen lomassa. Niitä kannattaakin ehdottomasti tehdä.

Klemola tarjoaa seikkaperäisen kuvauksen kehomielen käsitteestä, tietoisuuden rakenteesta sekä hengityksen ja tietoisuuden havainnoimiseen perustuvasta istumisharjoituksesta. Hän pohtii myös mindfulnessin sovelletta- 
vuutta ja buddhalaisen perinteen viitoittamaa etiikkaa.

\section{KEHOMIELEN SISÄLLÄ}

Kirjan parhainta teoreettista antia ovat kuvaukset mielen ja kehollisen kokemuksen rajaaman tajunnan rakenteesta. Tässä mennään pidemmälle kuin monessa mindfulness-oppaassa. Teoksen mukaan mindfulness, jota usein kuvataan "hyväksynnän", "irtipäästämisen" ja "vain olemisen" termein, on myös tahdon harjoittamista. Buddhalaisen psykologian tahto-käsitys on antoisa kenelle tahansa, eikä ihme, että juuri käyttäytymisterapioissa sitä on hyödynnetty. Klemola selventää, miten "pelkkä tarkkailu" on kaikkea muuta kuin passiivista toimintaa. Meditaatio on mielen väsymätöntä läpivalaisua.

Hengityksen tarkkailu on tärkein tapa mielen tutkimiseen ja sitä tehdään tyynyllä istuen, istumisharjoituksessa ("zazen"). Klemola käyttää taitavasti fenomenologista näkökulmaa sen osoittamiseen, etteivät keho ja mieli ole kokemuksessamme erillisiä. Ja koska kaikki on mieltä, meidän pitää tutkia mielemme toimintaa ymmärtääksemme sen vaikutusta kokemuksemme sisältöön. Klemola kuvaa tämän intressin yhteyksiä fenomenologiaan. Mindfulnessin tarkkailevalla intressillä voi nähdä yhteyksiä jopa etnometolodologiseen tutkimusperinteeseen.

Mietiskelyssä tutkiminen tapahtuu tarkkailemalla ja hidastamalla sitä, minkä yleensä sivuutamme huomattamatta. Yhtäältä, miten hengitämme ja "asumme" kehokokemuksessamme ja toi- saalta, miten tajunnan sisällöt (ajatukset, aistimukset, tunteet) viriävät alituiseen mielessämme. Mieli ei käyttäydy kuten toivoisimme. Tärkeätä on kuitenkin havaita mielemme sisältö "sellaisena kuin se on”. Tässä mielessä harjoitus ei voi epäonnistua: se vain on, mitä se on.

Erityisen kiinnostavana pidin tietoisuuden avaruudellista mallia ja siihen liittyviä harjoituksia. Antoisa oli myös mielen rakenteen havainnollistaminen oivalluttavin harjoittein. Humoristisen muistilauseen "Ykä, Kake, Pera ja mä" avulla viitataan egotietoisuuteen, kehotietoisuuteen, havainnoivaan itseen sekä näitä edellisiä kiinnittävään tietoisuuden perustaan. Tämä perusta on se tyyni piste, tajunnallisen sulautumisen kohta, jonka etsimiseksi meditaatioon voi myös hahmottaa.

Teoksen perusviestinä on purkaa kehon ja mielen välistä dualismia, jonka Klemola katsoo vaivaavan länsimaista kulttuuria. Hän käyttääkin "mielen" sijasta termiä "kehomieli". Harjoitusten ja käsitteellisen kuvauksen kautta hän auttaa hahmottamaan kehoon muitakin keskuksia kuin päähän sijoittuvan "ajattelualueen".

Itse tosin koen, että länsimaisessakin kulttuuripiirissä on kokonaisvaltaisen kehokokemuksen saarekkeita. Klemola mainitsee saunomisen, mutta entä luonnossa samoilu, liikunta, tanssiminen - tai vaikkapa kuukautiskierto, synnyttäminen, imettäminen, seksuaaliset kokemukset? Vaikka kirjassa puhutaan koko ajan kehosta, tuntuu välillä, että siinä esiintyvä keho on jotenkin siistitty, neutraali. Olenkin kokenut esimerkiksi amerikkalaisen Yoko Beckin zenteokset tärkeiksi siksi, että arkinen, tunteva, suhteissa elävä ruumis on niissä selvemmin mukana.

\section{MIKSI MIETISKELLÄ?}

Buddhalaisuuteen kuuluu egosta irrottamisen pyrkimys, koska egon pysyvyyttä pidetään pohjimmiltaan mielen tuottamana harhana. Meditaatiossa harha voi väljetä tai peräti purkautua. Valaistuminen mietiskelyn äärimmäisenä seuraamuksena tarkoittaa mielen toiminnan täyttä "läpivalaisemista”, sen sokeista pisteistä irtautumista ja siten kärsimyksestä vapautumista. Buddhalaisuudessa inhimillinen kärsimys nähdään seurauksena egon haluihin takertumisesta.

Monelle ajatus valaistumisesta voi olla vaikea, minulle ainakin on. Haluamisen ja kärsimisen loppuminen tuntuu ihmisenä olonkin loppumiselta. Sosiaalisen konstruktionismin kasvatille on myös vaikea vakavissaan tavoitella todellisuuden näkemistä "puhtaasti sellaisena kuin se on".

Harjoituksen mielekkyyden voi käsittääkseni nähdä myös ilman näin äärimmäistä pyrkimystä, kokemuksen rikastamisen ja viisastumisen näkökulmasta. Kuten Klemola toteaa, voimme "asua pidempään siinä kokemuksessa, jossa sisäinen puhe on vaiennut". Tutustumme tarkoituksella kehomielemme koko laajuuteen. Voimme siis viisastua tutkimusmatkasta "sisäänpäin" - emme ainoastaan yhteistyössä muiden 
kanssa tai reflektoimalla kokemuksiamme (jotka kaiketi ovat "lännelle" ominaisia viisastumisen muotoja). Kun saamme etäisyyttä egon sisäiseen puheeseen, pystymme vähitellen toimimaan harkitummin arvojemme suunnassa.

Mindfulness tarjoaa armahtavan näkökulman länsimaiselle suorittajalle: läsnäolon ja riittävyyden korostamisen, "aloittelijan mielentilaan" alati asettumisen, hyödyn ajatuksesta luopumisen. Toisin kuin monissa joogaperinteissä, mietiskelyssä ei etsitä "rakkaudellista", "lempeää" tai edes "aitoa" minää. Tarkastellaan vain sitä, mitä on. Klemola tosin muistuttaa, että buddhalaiseen etiikkaan kuuluu paitsi tietoisuuden tarkkailu, myös positiivisten mielentilojen viljely. Tämä jää kuitenkin sivuteemaksi.

\section{DIALOGINEN LUKUKOKEMUS}

Pidin kirjan selkeästä asiatyylistä. Vahvimmillaan teos on istumisharjoituksen, hengityksen tarkkailun sekä tajunnallisuuden kuvaamisessa. Summittaisemmaksi se muuttuu selostettaessa buddhalaisen etiikan näkökulmia.

Puutteena koin kielen teoretisoimisen käyttäytymisterapiapiireissä kehitellyn suhdekehysteorian kautta. Mindfulness-kirjallisuudessa mielen kielellisyyttä kuvataan usein pelkästään "miel- teitä suoltavan” sisäisen puheen näkökulmasta. Sen me toki kohtaamme, kun asetumme meditoimaan. Mielen kielelliselle rakentuneisuudelle tehtäisiin kuitenkin oikeutta, jos pohdittaisiin myös sosiaalisesti kontekstoituvaa, työskentelevää, keskittyvää ja suuntautunutta mieltä. Ihmismieli on toki virhealtis "instrumentti". Silti yritämme sen avulla operoida todellisuuden ja toistemme kanssa. Ihmismieltä ei voi hahmottaa kokonaisvaltaisesti, jos tarkastelu täysin irtoaa sosiaalisen toiminnan ja sosiaalisten suhteiden kontekstista.

Mietityttämään jää toinenkin teema: psyyken rakentumisen sekä terveen ja sairaan psyyken suhde mietiskelyssä tapahtuvaan egosta vapautumiseen. Aiheesta käydään vilkasta keskustelua Yhdysvalloissa. Siellä zenin harjoittaminen on laajentunut valtavasti ja monet terapeutit yhdistävät zenopettajuuden praktiikkaansa.

Klemola esittää mindfulnessin ytimen buddhalaisena ja toivoo, ettei sitä pelkistetä tekniikaksi. Itse yritän ajatella mietiskelyä yleisenä kategoriana. Se voi elää erilaisten perinteiden piirissä, erilaisin tavoitteenasetteluin. Itselleni harjoittamisen idea on auennut parhaiten vasta vertaillessani kahta erilaista kehomielen harjoitustapaa: joogaa ja istumismeditaatiota.
Pidän Klemolan teosta keskeisenä suomalaisessa mindfulnesskeskustelussa. Opin kirjan avulla ymmärtämään paremmin mindfulnessin buddhalaista taustaa ja sain muotoiltua myös omia erimielisiä kantojani. Lukukokemus oli siten kunnioittavan dialogin kaltainen. Klemola opettaa viisaasti.

Sanna Vehviläinen

dosentti, työnohjaaja, projektipäällikkö Campus Conexus Tampereen yliopisto 